\title{
A Neutraceutical by Design: The Clinical Application of Curcumin in Colonic Inflammation and Cancer
}

\author{
D. Soni and B. Salh \\ Division of Gastroenterology, Department of Medicine, The University of British Columbia, Vancouver, BC, Canada V5Z 1 M9 \\ Correspondence should be addressed to B. Salh; bill.salh@ubc.ca
}

Received 10 July 2012; Accepted 26 August 2012

Academic Editors: A. Asai and W. Vogel

Copyright (C) 2012 D. Soni and B. Salh. This is an open access article distributed under the Creative Commons Attribution License, which permits unrestricted use, distribution, and reproduction in any medium, provided the original work is properly cited.

\begin{abstract}
Unquestionably, the natural food additive curcumin, derived from the colorful spice turmeric used in many Asian cuisines, possesses a diverse array of biological activities. These range from its anti-inflammatory, antineoplastic, and metabolic modifying properties to surprising roles in disorders ranging from Alzheimer's disease to cystic fibrosis. Its effects on growth factor receptors, signaling molecules, and transcription factors, together with its epigenetic effects are widely considered to be extraordinary. These pleiotropic attributes, coupled with its safety even when used orally at well over $10 \mathrm{~g} / \mathrm{day}$, are unparalleled amongst pharmacological agents. However, there is one drawback; apart from the luminal gastrointestinal tract where its pharmacology predicts that reasonable drug levels can be attained, its broader use is hampered by its poor solubility and hence near undetectable plasma levels. Medicinal chemistry and nanotechnology have resulted in the generation of compounds where the modified drug or its delivery system has improved matters such that this shortcoming has been addressed to some extent, with the surprising finding that it remains safe to use. It is predicted that either the parental compound or its derivatives may eventually find a place in the therapeutic management protocols of several conditions.
\end{abstract}

\section{Background}

Gastrointestinal disorders in general are probably the commonest reasons for patients seeking medical attention. Whilst many of these are short-lived and due to minor infectious illnesses and food intolerances, there are still a significant number of more serious and chronic problems that demand ongoing or more involved care [1]. This is especially true of gastrointestinal cancers, that include colorectal cancer and chronic inflammatory diseases such as Crohn's disease and Ulcerative colitis.

Colorectal cancer is one of the leading causes of morbidity and mortality worldwide; contributing to $8 \%$ of all cancer deaths, it is the third most common cancer in women and fourth most common cancer in men $[2,3]$. An estimated 1.2 million new colorectal cancer cases are detected annually, accounting for approximately 630000 deaths per year. Patients with inflammatory bowel disease (IBD) have a strong predisposing risk for colorectal cancer [4]. IBD is a broad term, comprising Crohn's disease (CD) and Ulcerative colitis (UC). The unification of the two under a common banner rests on a mutually shared pathophysiology: environmental factors (e.g., normal luminal flora) inciting host immune dysregulation in genetically predisposed individuals [5]. This process involves CD4+ lymphocytes, macrophages, neutrophils, and their corresponding inflammatory mediators, with the ensuing immune response eliciting a chronic, destructive inflammatory process and associated intestinal epithelial barrier dysfunction. Of all the modes of human colorectal cancer induction (e.g., adenoma-carcinoma sequence or chromosomal instability pathway, hereditary nonpolyposis colon cancer or HNPCC, and colitis-associated), colitisinduced colorectal cancer (CAC) is unique in its pathophysiology, involving inducible nitric oxide synthase (iNOS)mediated free radical injury in the setting of a persistently inflamed mucosa [6]. The significant impact of IBD's relapsing and remitting nature on patient well-being, coupled with its malignant potential, has led to the development of a variety of biological drugs such as antitumor necrosis factor alpha (a-TNF $\alpha$ ) antibodies [7]. These have dramatically altered the outlook for patients with IBD. However, there are limitations associated with their use that include cost and significant 
infectious complications; these factors are now leading to a search for novel treatment options.

Curcumin is a yellow pigment found in the Indian curry spice, turmeric, and has been credited as a natural treatment for a variety of diseases. Today, this food agent is being increasingly recognized in complementary and alternative medicine (CAM) for its anti-inflammatory, antimicrobial, anticarcinogenic, antiproliferative, and free radical scavenging activity [34, 35]. In particular, its mainly intestinal localization has specified it as an agent for investigation predominantly in bowel pathology. Once overlooked, natural remedies such as curcumin are attracting increasing interest over the conventional mainstays of treatment that include 5-aminosalicylates (mesalamine), corticosteroids, immune modulators (e.g., methotrexate, azathioprine), biologic therapies such as anti-TNF $\alpha$ (infliximab, adalimumab), and anti$\alpha 4 \beta 7$ antibodies (natalizumab) in IBD $[32,33]$. Importantly, studies have shown IBD and CRC to be less common in developing countries than developed nations with eastern emigrants gradually assuming the western risk for disease $[36,37]$. Interestingly, our studies have shown an increasing trend for IBD amongst migrants from south Asia, but colon cancer remains uncommon [38, 39]. This, again, highlights the importance of diet in these disorders and engenders greater interest in nutritional therapies such as curcumin for treatment.

\section{Structural Anatomy of Curcumin}

First isolated in 1815, and chemically identified as a bis $\alpha, \beta$ unsaturated $\beta$-ketone known as diferuloylmethane [1,7-bis-(4-hydroxy-3-methoxyphenyl)-1,6-heptadiene-3,5dione], curcumin is a hydrophobic polyphenol conferring bioactive properties to the rhizomatous herb turmeric (curcuma longa). It constitutes 5\% of the plant's root [40], the remaining composition being assigned to carbohydrate, protein and essential oil contaminants. Anatomically, it is a linear diarylheptanoid comprising of 2 oxy-substituted aryl moieties held together through a 7-carbon chain. Three natural analogues of this pleiotropic compound, known collectively as curcuminoids, have been identified. Each curcuminoid contains the basic aromatic ring native to the original compound, but is differentiated by a unique methoxy group substitution in place of the aryl moieties. Curcumin is the most abundant, comprising $77 \%$, demethoxycurcumin (17\%), and finally bismethoxycurcumin (3\%) [41]. Despite being structurally distinct, curcuminoids have similar biological properties. These physiological attributes are reliant on the biochemical makeup of the compound, an example being the common carbonyl and phenolic hydroxyl groups which are believed to bestow anti-inflammatory and antioxidant action to curcumin compounds, respectively. With a variable response elicited by different organ systems and their individual cellular constituents, unanimity over the most effective compound remains to be achieved, the data suggesting that curcuminoids are only synergistically more potent than any of their individual counterparts with no single analogue having greater activity compared to the next
[42]. Pharmacological preparations exist as purified extracts or synthetic compositions of curcuminoids, the original powder form being cast into a convenient pill form for oral use.

A favorable safety profile relative to existing therapies adds to curcumin's appeal as a medicinal therapy. Dosage regimens up to $12 \mathrm{~g} /$ day are deemed well tolerated in humans [27], but achieving doses above $8 \mathrm{~g}$ /day has proved difficult due to the bulky structure of the compound [26]. Peak concentrations are achieved 1-2 hours after oral application dissipating to undetectable serum levels after 12 hours. Oral dosage below 4 grams has similarly rendered serum detection negligible in some studies [27]. However, availability in the gut remains comparatively higher with oral doses of even 3-6 grams showing evidence of accumulation in colorectal mucosal cells, making the bowel a prime target for therapy [31]. Human studies till date have evidenced the therapeutic efficacy of curcumin with rare patient diarrhea reported. Longer-term studies have paradoxically questioned possible tumorigenic qualities of the phytochemical at higher serum concentrations, necessitating further insight into an acceptable therapeutic range for use [43]. Studies in the Indian population have still maintained safety of lifelong curcumin ingestion up to about $100 \mathrm{mg} /$ day [44], the turmeric extracts and curcumin have been tested for mutagenicity using the Ames test and have been found to be nonmutagenic [45] and the United States Food and Drug Administration has also classified the turmeric among substances Generally Recognized as Safe (GRAS).

Nevertheless, the manifold advantages of this food agent are counterbalanced by a pharmacokinetic pitfall: low bioavailability attributed to (1) poor absorption, (2) extensive first pass metabolism, (3) rapid elimination, due to hepatic glucuronidation and sulfation of the compound, and (4) poor aqueous solubility [46]. Understandably, this has accelerated the development of curcumin derivatives, which in contrast to distinct structural analogues, are in fact curcumin cores with additional functional groups (e.g., glycosyl, acetyl) [41]. One such derivative, a diphenyl difluoroketone known as EF24, has been shown to offer greater biological activity in the setting of similar toxicity as traditional curcumin [47]. Other approaches in the form of liposomal preparations, nanoparticle-based systems, and even adjuncts such as piperine and quercetin have been developed to augment curcumin's accessibility. Studies have additionally demonstrated use of heat application to curcumin as a promising means of enhancing its water solubility [48]. Metabolites of curcumin have also proved therapeutically beneficial, potentially harboring biological activity. Of these, tetrahydrocurcumin, the reduced form of curcumin, has been predominantly investigated. It lacks the yellow color and hydrophobicity of its parent compound, but despite reduced efficacy as an anti-inflammatory agent (decreased NF- $\kappa \mathrm{B}$ inhibition) demonstrates greater potency as an antioxidant [49].

Curcumin is known to interact with a number of targets both directly and indirectly through covalent as well as noncovalent, and hydrogen bonding. Many of these have been characterised using a computational method known as molecular docking. Curcumin's intriguing ability to bind to a 
multitude of different molecules is thought to be due to the fact that it contains a central beta diketone moiety, and in part due to the phenyl rings. It is capable of existing as a ketoenol tautomer, which in effect allows the molecule to undergo hydrogen bonding. Some of its most important directly interacting molecules include inflammatory molecules such as Cox- 2 and $\mathrm{TNF} \alpha$, enzymes such as histone acetyltransferases (HATs), protein kinases such as Src and glycogen synthase kinase $3 \beta$, and a variety of other molecules including RNA and DNA. For example, in the case of GSK3 $\beta$, the curcumin is bound to valine 135 and arginine 141 through hydrogen bonding (for an excellent review on this topic see [50]).

One intriguing property ascribed to curcumin is that it has epigenetic effects, which translates into an ability to affect gene regulation without actually changing the DNA sequence. In this regard it has been shown to be a stronger inhibitor of HDAC than butyrate even. The acetylation of transcription factors such as NF- $\kappa \mathrm{B}$ and GATA4 has also been shown to be inhibited by curcumin. One very promising area of research has addressed the role of curcumin in regulation of miRNAs. These are short lengths of nucleotides, which have the capacity to bind to the $3^{\prime}$ untranslated portion of messenger RNAs, and may interfere with their transcription and translation. Some of these miRNAs have been shown to play significant biological roles in the development of cancer and mediate properties such as epithelialto-mesenchymal transition (EMT), an important attribute of cancer cells thought to be integrally involved in tissue invasion. Specifically, in this area miRNAs 21 and 200 have been demonstrated to be inhibited by curcumin [51].

\section{Molecular Etiology and Biochemical Effects}

3.1. In Vitro Studies. Chronic inflammation has been established as a noted cause of cancer [52], and it is widely accepted that treatment of IBD, together with induction of mucosal healing, also decreases the consequent risk for CRC. The molecular targets attributed to curcumin's healing qualities can be primary or secondary in nature. Primary targets are acted upon directly, while those secondarily or indirectly modified are those positively or negatively regulated according to their respective target. A key primary target in the path to mediation of the inflammatory response by curcumin is nuclear factor-kappa $\mathrm{B}(\mathrm{NF}-\kappa \mathrm{B})$ [53]. This ubiquitous transcription factor is responsible for the regulation of expression of proinflammatory molecules including TNF $\alpha$, IL-1, IL-6, COX-2, and 5-lipoxygenase (Table 1). NF- $\kappa \mathrm{B}$ activation results from the dissociation of its heterotrimeric structure ( $\mathrm{p} 50, \mathrm{p} 65$, and $\mathrm{I} \kappa \mathrm{B} \alpha)$, via the phosphorylation and degradation of $\mathrm{I} \kappa \mathrm{B} \alpha$ through the proteosome. This results in the nuclear translocation of p50 and p65 components and initiation of transcription of inflammatory factors. Curcumin appears to reduce phosphorylation of $\mathrm{I} \kappa \mathrm{B} \alpha$ and its degradation by inhibiting IKK signalling [54, 55]. Inflammatory mediators arising from NF- $\kappa$ B activation (e.g., IL-6) additionally act upon signal transducer and activator of transcription 3 (STAT-3), another pivotal cytoplasmic transcription factor, whose regulated

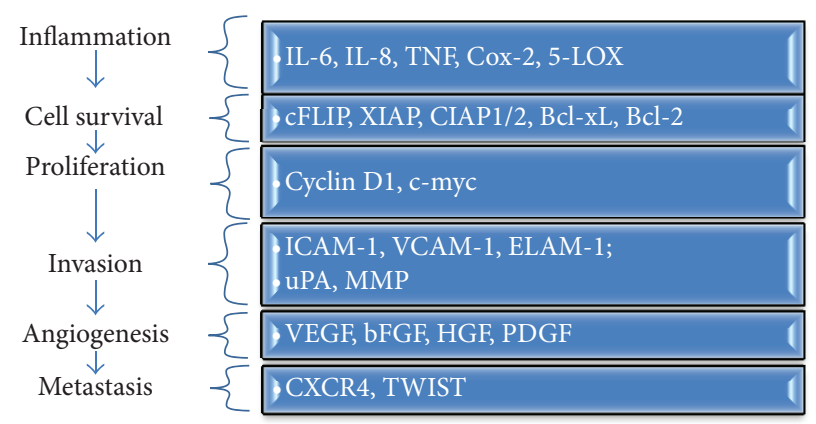

FIGURE 1: NF- $\kappa$ B regulated molecules, directly or indirectly affected by curcumin, and their point of action in carcinogenesis.

gene products are linked with cell survival, growth, and angiogenesis. This process is reversibly inhibited by curcumin [55].

The most prevalent genetic defect associated with Crohn's disease is mutation in the intracellular pattern recognition receptor known as NOD2 (nucleotide binding oligomerization domain 2) [56]. This is part of the complex set of pathogen recognition receptors (PRRs) required for defense against mucosal pathogens. Together with NOD1, which acts as a sensor of Gram-negative bacteria, and NOD2, which likely acts as a sensor for both Gram-positive and Gramnegative, the toll-like receptors (TLRs) are key components maintaining normal gut microbial homoeostasis. Notably in this regard, genetic deletion studies indicate that both NOD1 and NOD2 knockouts have increased gastrointestinal sepsis. An interesting work indicates that curcumin is able to inhibit NOD2 signaling [57]. The relevance of this remains uncertain as it may have a positive or negative impact on chronic inflammatory disorders such as Crohn's disease.

A significant proportion of genes linked with carcinogenesis is regulated by NF- $\kappa \mathrm{B}$ and STAT-3; curcumin's pharmacological versatility compared to other natural antiinflammatory agents is demonstrated by it being the sole agent capable of inhibiting both factors. One of the integral hallmarks of cancer is cancer cell survival, and curcumin is able to block this via a number of molecules with a clear involvement in survival mechanisms, several of which are NF- $\kappa$ B dependent such as cFLIP, BCL-xL, BCL-2, XIAP, CIAP1, CIAP2, and surviving [58-63]. As these molecules may also mediate chemoresistance, it was important to show that curcumin could reverse this process through their downregulation [64]. This highlights both negative modulation of growth/proliferation pathways and galvanization of apoptotic pathways (e.g., caspase activation) [62] as an important means of inhibiting cell survival by this agent. Studies also indicate a role for curcumin in sphingomyelinase signaling with the effects on ceramide generation and ROS production mediating cell apoptosis and contributing to decreased cancer incidence $[65,66]$. Cell proliferation (e.g., COX-2, cyclin D, c-myc [67-69]), angiogenesis (e.g., VEGF [70]), and invasion and metastasis (e.g., MMP-9, CXCR4, TWIST [71-73]) are also ascribed to the secondary actions of NF- $\kappa$ b and STAT-3 (Figure 1). 
TABLE 1: Curcumin: a list of animal studies demonstrating anti-inflammatory, chemopreventive, and chemotherapeutic action in gastrointestinal disease (IBD and CRC).

\begin{tabular}{lll}
\hline Author, year & Animal model & Dosage regimen \\
\hline Sugimoto et al., 2002 [8] & TNBS colitis; & Dietary; 0.5, 2.0, and 5.0\% \\
& $\begin{array}{l}\text { C57BL/6 and } \\
\text { BALB/c mice }\end{array}$ & 7 days \\
& & \\
& & \\
& $\begin{array}{l}\text { Min/+ mice and } \\
\text { wild-type C57Bl/6J } \\
\text { mice }\end{array}$ & $\begin{array}{l}\text { Dietary; 0.1\%, 0.2\%, and 0.5\% } \\
\text { 15 weeks or single dose } \\
\text { intraperitoneal injection }\end{array}$ \\
Perkins et al., 2002 [9] &
\end{tabular}

Findings

Inhibits Th1 cytokine profile in CD4+ T cells by suppressing IL-12 production in macrophages; proposed mechanism: NF- $\kappa$ B downregulation

Concluded curcumin useful in the chemoprevention of human intestinal malignancies related to Apc mutations (advantage over NSAIDS in is its ability to decrease intestinal bleeding linked to adenoma maturation)

At 0.2 and $0.5 \%$, it reduced adenoma multiplicity by 39 and $40 \%$, respectively

Hematocrit values in untreated mice were drastically reduced

\begin{tabular}{lll}
\hline Perkins et al., 2003 [10] & Apc (Min/+) mice & $\begin{array}{l}\text { Dietary; 0.2\% and or aspirin } \\
(0.05 \%)\end{array}$ \\
\hline Ukil et al., 2003 [11] & $\begin{array}{ll}\text { TNBS colitis; } \\
\text { BALB/c mice }\end{array}$ & $\begin{array}{l}\text { Dietary; 50, 100, and } \\
300 \mathrm{mg} / \mathrm{kg} ; 10 \text { days before } \\
\text { treatment and } 8 \text { days after } \\
\text { induction }\end{array}$ \\
\hline Salh et al., 2003 [12] & DNBS colitis; C3H & $\begin{array}{l}\text { Dietary; } 0.25 \% \\
5 \text { days before treatment and } 5 \\
\text { days after induction }\end{array}$ \\
& mice &
\end{tabular}

Aspirin and curcumin act during different "windows" of neoplastic development

Significant reduction in neutrophil infiltration (decreased MPO activity), lipid peroxidation (decreased malondialdehyde activity), and decreased serine protease activity.; also reduction in IFN-, IL-12, iNOS mRNA expression, and NF- $\kappa \mathrm{B}$ NF- $\kappa$ B inhibition; reduced MPO activity, IL- $1 \beta$ activity, and p38 MAPK activity

Reduced weight loss, histological severity, and reduction in inflammatory markers

NF- $\kappa \mathrm{B}, \mathrm{I} \kappa \mathrm{B}, \mathrm{IL}-1$, and IL-10 improved histological score, suppression of NF- $\kappa$ B, blockage of $\mathrm{I} \kappa \mathrm{B}$

$\begin{array}{ll}\text { Jian et al., 2005 [13] } & \text { TNBS colitis; SPF Distar rats }\end{array} \quad$ Dietary; 2.0\%, 14 days degradation, suppression of IL-1, and increase IL-10 expression

\begin{tabular}{lll}
\hline & TNBS colitis; & 30 and $60 \mathrm{mg} / \mathrm{kg}$ day, \\
Jiang et al., 2006 [14] & $\begin{array}{l}\text { Sprague-Dawley } \\
\text { rats }\end{array}$ & 14 days \\
\hline
\end{tabular}

Reduced MPO activity, decreased COX-2, IFN- and TNF-expression, and increased PGE2 expression

Reduced myeloperoxidase (MPO) activity Decreased the expression of Th1 cytokines (IL-12, IFN-gamma, TNF-alpha, and IL-1)

Zhang et al., 2006 [15]

TNBS colitis; Sprague-Dawley $30 \mathrm{mg} / \mathrm{kg} /$ day, intraperitoneal rats injection Increased the expression of Th2 cytokines (IL-4 and IL-10) Increased proportion of IFN-gamma/IL-4 in splenocytes and circulation Improved weight loss and histological images

\begin{tabular}{lll}
\hline Venkataranganna & DNCB colitis; & Dietary; 25, 50, and $100 \mathrm{mg} / \mathrm{kg}$ \\
et al., 2007 [16] & Wistar rats & 10 days \\
\hline
\end{tabular}

Down-regulation of iNOS and NF- $\kappa \mathrm{B}$ expression Decrease in MPO, LPO, and ALP activities

Reduced MPO activity and tumour necrosis factor alpha (TNF)-alpha

Diminished p38 MAPK activity; decreases COX-2 and iNOS expression Reduced nitrites

Camacho-Barquero
et al., 2007 [17]

$\begin{array}{ll}\text { TNBS colitis } & \text { Dietary; } 50-300 \mathrm{mg} / \mathrm{kg} \\ & 14 \text { days }\end{array}$

Reduced nitrites

Reduction in the activation of p38 MAPK

Dietary; $45 \mathrm{mg} / \mathrm{kg}$;

\pm capsazepine

$\begin{array}{ll}\text { Martelli et al., 2007 [18] } & \text { DNBS colitis; } \\ \text { BALB/c mice }\end{array}$ intraperitoneally, (30 min before curcumin) Down-regulation of COX-2 and iNOS expression Reductions in MPO activity and (TNF)-alpha Reduced nitrites

7 days

$\begin{array}{lll}\text { Deguchi et al., 2007 [19] } & \text { DSS colitis; } & \text { Dietary; 2.0\% wt/wt } \\ \text { BALB/c mice } & 14 \text { days }\end{array}$

Reduced disease activity index, histological colitis score, and MPO activity Suppressed NF- $\kappa$ B activity 
TABle 1: Continued.

\begin{tabular}{|c|c|c|c|}
\hline Author, year & Animal model & Dosage regimen & Findings \\
\hline $\begin{array}{l}\text { Billerey-Larmonier } \\
\text { et al., } 2008[20]\end{array}$ & $\begin{array}{l}\text { TNBS colitis; } \\
\text { BALB/c and SJL/J } \\
\text { mice }\end{array}$ & $\begin{array}{l}\text { Dietary; } 2.0 \% \mathrm{wt} / \mathrm{wt} \\
9 \text { days }\end{array}$ & $\begin{array}{l}\text { BALB/c mice: curcumin significantly increased } \\
\text { survival, prevented weight loss, and normalized } \\
\text { disease activity } \\
\text { SJL/J mice: curcumin demonstrated no protective } \\
\text { effects }\end{array}$ \\
\hline Larmonier et al., 2008 [21] & $\begin{array}{l}\text { Specific } \\
\text { pathogen-free } \\
\text { wild-type } 129 / \text { SvEv } \\
\text { mice and IL-10 } \\
(-/-) \text { mice }\end{array}$ & $\begin{array}{l}\text { Dietary; } 0.1-1 \% \mathrm{wt} / \mathrm{wt} \\
14 \text { days }\end{array}$ & $\begin{array}{l}\text { Reduced IFN-gamma and IL-12/23p } 40 \text { in SPF mice } \\
\text { (limited effects in IL-10 mice) } \\
\text { Synergistic action of curcumin and IL-10 to inhibit } \\
\text { NF- } \kappa \text { B }\end{array}$ \\
\hline Nones et al., 2009 [22] & mdrla $-/-$ mice & $\begin{array}{l}\text { Dietary; } 0.2 \% \\
16-19 \text { weeks }\end{array}$ & $\begin{array}{l}\text { Upregulation of xenobiotic metabolism and a } \\
\text { down-regulation of proinflammatory pathways } \\
\text { (possibly mediated by pregnane X receptor (Pxr) and } \\
\text { peroxisome proliferator-activated receptor alpha } \\
\text { (PPARA) activation of retinoid X receptor (Rxr)) }\end{array}$ \\
\hline Lubbad et al., 2009 [23] & $\begin{array}{l}\text { TNBS colitis } \\
\text { Sprague-Dawley } \\
\text { rats }\end{array}$ & $\begin{array}{l}\text { Dietary; } 100 \mathrm{mg} / \mathrm{kg} \\
5 \text { days }\end{array}$ & $\begin{array}{l}\text { Reduced MPO and MDA concentrations in colitis } \\
\text { models } \\
\text { Diminished TLR- } 4, \mathrm{NF}-\kappa \mathrm{B} \text {, and MyD88 proteins in } \\
\text { colitis models }\end{array}$ \\
\hline Jia et al., 2011 [24] & $\begin{array}{l}\text { DSS colitis; } \\
\text { C57BL/6 mice }\end{array}$ & $\begin{array}{l}\text { Dietary; } 2 \% \text { curcumin } \pm \text { fish } \\
\text { oil } \pm \text { maize oil }\end{array}$ & $\begin{array}{l}\text { Combined FO and curcumin suppressed NF- } \kappa \mathrm{B} \text {, in } \\
\text { the colon mucosa }\end{array}$ \\
\hline
\end{tabular}

A prime secondary target, indirectly mediated by curcumin through NF- $\kappa \mathrm{B}$ inhibition, is COX-2 [74], which is an inducible gene; its enzymatic product cycloxygenase- 2 is an important intermediary in arachidonic acid metabolism. Evidence from several lines of investigation indicates that prostaglandin E2, a metabolite of arachidonic acid, plays an important role in colon cancer development [75-77]. The importance of COX-2 in colorectal cancer treatment is further substantiated by the mode of action ascribed to nonsteroidal anti-inflammatory drugs (NSAIDs) such as aspirin, which are shown to inhibit COX-2, offering a potential mechanism for reducing the risk of colon cancer [78]. As such, COX-2 inhibition hinders tumorigenesis through proapoptotic means as well as curtailing means of tumor persistence via inhibition of angiogenesis (the growth of new blood vessels) [79]. Curcumin appears to be equivalent to NSAIDs in this respect but has a more favorable toxicity profile [28], hence having significant potential for long-term bowel cancer treatment and prevention in humans.

Curcumin has been shown to inhibit vascular growth factors and zinc-dependent endopeptidases, known as matrix metalloproteinases, thus antagonizing fundamental means of tumor invasion and propagation. In a study of both primary bovine and immortalized mouse endothelial cells, curcumin inhibited endothelial cell proliferation [80]. Inhibition of angiogenesis in response to vascular endothelial growth factor (VEGF) in the human intestinal microvascular endothelium has also been demonstrated [81], together with impairment of human umbilical vein endothelial cell differentiation [82]. In human hepatocellular carcinoma cells, this phytochemical decreases hypoxia-inducible factor- $1 \alpha$ (HIF1 $\alpha$ ), a known angiogenic transcriptional activator [83].
Additionally, alongside angiogenesis, tumour spread also requires ability for basement membrane invasiveness. Here, curcumin irreversibly inhibits and downregulates production of certain membrane-bound matrix metalloproteinases [84], with studies in human fibrosarcoma cell lines honing in on MMP-9 and MMP-2 as the main targets [85]. MMP-9 has also been reduced in human intestinal epithelial cells [64]. These collagenases are responsible for cell membrane disintegration allowing cells to invade and metastasize. Recently, the dosedependent inhibition of MMP-3 has been identified in primary human colonic myofibroblasts isolated from patients with inflammatory bowel disease [86].

The p53 tumor suppressor gene is another molecule altered by curcumin administration. Here, divergent modification is observed. Studies in colon cancer cell lines (RKO cells) have evidenced a decline in p53 activity through impaired posttranslational modification of the gene product [87]. Nonetheless, differential activity was observed in normal B cells, which displayed minimal p53 activity. This phenomenon is echoed in studies of immature B-cell lymphoma mouse cell lines (BKS-2 and WEHI-23 cells) where inhibition of p53 was observed despite reduced cell proliferation [88]. In contrast, in the HT-29 human colon adenocarcinoma cell line, p53 induction was seen [89], supported by similar investigations in multiple other human cell studies of prostate, B-cell lymphoma and breast epithelial lineages [90]. Collectively, these studies indicate that additional factors may affect the ability of curcumin to impact on p53 function, but overall a proapoptotic role is favored.

Curcumin's unique pharmacological nature is further underscored by its effects on mitogen-activated protein 
kinases (MAPKs), which are important signaling intermediates for many biological processes and are activated by various receptors including growth factors, cytokines, tolllike receptors, and stress. Inhibition of this enzymatic cascade in human intestinal microvascular endothelial cells implies beneficial antiangiogenic action in response to VEGF, COX-2 and PGE2 [70]. More specifically, in colonic mucosal biopsies and colonic myofibroblasts isolated from children and adults with active IBD, curcumin also reduced p38 MAPK activation [86]. Conversely, the activation of MAPK by curcumin, for example, c-Jun N-terminal kinase (JNK) in HCT116 cells, a human colon cancer cell line [91] and p38 MAPK in primary human neutrophils [92] has also been demonstrated. The signaling mechanisms invoked by curcumin exposure proved beneficial in all respects manifesting as antineoplastic, anti-inflammatory, and antiangiogenic effects as mentioned. Generally, it is recognized that the p38MAPK and the JNKs are examples of stress-activated protein kinases, and more likely to be associated with pro-inflammatory effects and apoptosis.

The activity of PPAR $\gamma$, a nuclear receptor that heterodimerizes with retinoic $\mathrm{X}$ receptors (RXRs) and is involved in a variety of diseases, is also augmented by curcumin, leading to reduced expression of cyclin D1 and inhibition of epidermal growth factor. The resulting disruption of the cell cycle has been demonstrated with studies in Moser cells (a human colon cancer cell line) and provides another example of the remarkable versatility of this compound [93].

3.2. Animal Studies. Experimental studies in animal models have been widely used to demonstrate the beneficial therapeutics of curcumin in IBD and colon cancer (see Table 1). In mainly rodent models of carcinogenesis, its efficacy for colon cancer treatment and prevention has been well documented $[94,95]$.

Three studies, including our own, were the first to report the beneficial effects of curcumin in experimental models of inflammatory bowel disease $[8,11,12]$. These studies have been replicated by many other groups and have shown that curcumin treatment is associated with a reduction in colonic NF- $\kappa \mathrm{B}$ activation, Th1 cytokine profiles (e.g., IL-12), p38MAPK activation, protease activity, iNOS mRNA expression, and oxidative stresses, including MPO and lipid peroxidation $[13,15,17]$. Furthermore, it has been demonstrated that a daily diet of curcumin $(30 \mathrm{mg} / \mathrm{kg}$ body weight/day) for 2 weeks in rats minimizes the ability of macrophages to generate reactive oxygen species and decreases the secretion of the lysosomal enzymes collagenase, elastase, and hyaluronidase [96]. Neutrophils represent a double-edged sword; while vital for proper immune functioning in damaged and inflamed tissues, they may also mediate epithelial injury [97]. Studies in BALB/C mice utilizing peritoneal macrophages and colonic epithelial cells show curcumin hinders neutrophil motility by antagonizing the expression and production of chemoattractant molecules, macrophage inflammatory protein 2 (MIP2), keratinocyte chemoattractant $(\mathrm{KC})$, macrophage inflammatory protein 1 (MIP1), and IL-1 in the mice. In the same study, curcumin also is shown to directly block neutrophil chemotaxis [98].
Dose-dependent studies in trinitrobenzene sulfonic (TNBS) acid colitis in rats have added another layer to our understanding of curcumin bioactivity. In NKT-deficient SJL/J mice, a classic $\mathrm{T}$ helper cell Th1-type response is present, while BALB/c mice display both Th1/Th2 activities [20]. In this study, it was found that curcumin ameliorated disease in relation to all parameters studied only in the $\mathrm{BALB} / \mathrm{c}$ mice. The reason for differing efficacies of curcumin in these two models remains unclear; however, it is suggestive of a restricted therapeutic benefit of curcumin that is dependent upon only certain immune alterations in IBD. Further dose-related studies in IL-10 knockout mouse, which simulated a Th1-type inflammation in the bowel unique to CD (versus Th2 model of UC), demonstrated a moderate dose-dependent effect detected only at the lowest dietary concentration of $0.1 \%$ [21]. Here, NF- $\kappa$ B activation in the gut was refractory to curcumin treatment at any concentration, with a requirement for IL-10 activity to achieve this effect in epithelial cells.

From the gastrointestinal perspective, since curcumin has been shown to influence inflammation as well as cancer, and since inflammation-associated cancer is common throughout the GI tract, it was a logical extension to investigate models of colitis-associated cancer (CAC) as well as the effect of curcumin upon standard models of colon cancer, with a particular focus on inflammatory components. Hence, using repeated cycles of DSS-induced inflammation in C57BL/6 mice, one group has shown that curcumin is able to prevent the development of obvious macroscopic cancers. Only minor lesions were seen and this was associated with a reduction in the level of nuclear translocation of $\beta$-catenin. Interestingly, there were reductions in the levels of COX-2, i-NOS, TNF $\alpha$, and interferon-gamma (IFN $\gamma$ ) [99].

Using a different approach and looking at APC mice, Murphy and colleagues showed that the administration of curcumin reduced the number of intestinal polyps by $75 \%$. They were also able to show a reduction in the amount of TNF $\alpha$ in the curcumin-treated mice as well as reductions in IL-1, IL-6, and CCL2, all of which are deemed to be important players in inflammation-associated cancer [100].

The increasing incidence of obesity within western populations is associated with a proinflammatory state. This may be associated with an increasing incidence of cancers such as that of the colon. Using " $\mathrm{db} / \mathrm{db}$ " obese mice, Kubota and colleagues were able to show that curcumin reduced the number of preneoplastic lesions [101]. In common with the other studies a reduction in the levels of TNF $\alpha$, IL- 6 , and COX-2 was found. Furthermore, curcumin was also shown to reduce the levels of leptin and fat weights.

In a more standard model of AOM-DSS-induced model of CAC, we have also shown a dramatic reduction in the number of neoplasms which was associated with impressive reductions in activity of AKT, expression of ILK, and nuclear translocations of both NF- $\kappa \mathrm{B}$ and $\beta$-catenin. Furthermore, we were able to show that reductions in the level of ILK were likely mediated through the proteosome as inhibition of this 
led to partial restoration of ILK levels (see [102], manuscript submitted).

Collectively, the above studies indicate an important role for a curcumin in vivo in several models of "inflammation-" associated cancer of the colon.

3.3. Human Studies. Curcumin's ability to inhibit the expression of proinflammatory stimuli has been shown clinically beneficial for patients with rheumatoid arthritis, psoriasis, postoperative inflammation, chronic anterior uveitis, and orbital inflammatory pseudotumours [103-108]. In the realm of gastrointestinal disease, curcumin shows clinical benefit in irritable bowel syndrome [109], tropical pancreatitis [110], gall bladder and biliary motility [111], gastric ulceration [112], IBD [32], and familial adenomatous polyposis coli [113]. While numerous experimental studies, both in vitro and colitis-simulated animal studies, have served to outline the myriad of curcumin effects in IBD and cancer, clinical studies in humans subjects remain scarce (see Table 2). Phase I clinical trials have facilitated recognition of this food agent as a safer mode of chemoprevention. Pilot dose-escalation studies in patients refractory to standard chemotherapy have demonstrated minimal side effects with doses up to $8,000 \mathrm{mg} /$ day for 3 months [26]. A similar study demonstrated that a third of cancer patients given curcumin upto $2.2 \mathrm{~g}$ per day experienced radiologically stable disease over the course of 3 months or longer, with one patient exhibiting abatement in severity of primary colorectal cancer, indicated by a drop in levels of relevant tumor markers, thus hinting at a potential role of curcumin in tumor regression [28]. So far, there have been limited human studies with curcumin and IBD outlining its beneficial role. In a pilot study, Holt and colleagues reported its use in ulcerative proctitis and $\mathrm{CD}$ [32]. Five patients with ulcerative colitis were given $550 \mathrm{mg}$ curcumin twice daily for 1 month followed by $550 \mathrm{mg}$ three times daily for another month. All the 5 patients improved as indicated by reductions in concomitant medications in four. Similarly, five patients with $\mathrm{CD}$ were treated with $360 \mathrm{mg}$ curcumin three times daily for 1 month with similar dosage four times daily for another two months. Here, four out of five demonstrated improvement in disease parameters as evidenced by lower Crohn's Disease Activity Index (CDAI) scores (mean reduction of 55 points), decreased ESR (mean reduction of $10 \mathrm{~mm} / \mathrm{hr}$ ), and reduced CRP by a mean of $0.1 \mathrm{mg} / \mathrm{dL}$. Symptomatic improvement in these patients was also documented $(P \leq 0.02)$. In another study, Hanai et al. [33] recruited eighty-nine patients with quiescent UC in a randomized, double-blind, multicenter trial of curcumin. Forty-five patients received $1 \mathrm{~g}$ curcumin twice a day alongside sulfasalazine or mesalamine, with the remaining 44 patients receiving placebo plus sulfasalazine or mesalamine for a period of 6 months. Of the 45 patients, 43 maintained a satisfactory study protocol and of those 43 who received curcumin, two relapsed during 6 months of therapy (4.65\%). 8 of 39 patients $(20.51 \%)$ in the placebo group relapsed $(P=0.040)$. Recurrence rates evaluated on the basis of intention to treat showed a significant difference between curcumin and placebo $(P=0.049)$. Furthermore, curcumin improved both the clinical activity index $(P=$ $0.038)$ and the endoscopic index $(P=0.0001)$ measures used to evaluate the morbidity associated with UC. The results of these studies favour curcumin as a promising and safe medication for maintaining remission in patients with quiescent $\mathrm{UC}$ as well as bolstering symptomatic improvement in those with proctitis and CD.

Recently, the administration of either 2 or $4 \mathrm{~g}$ of curcumin to smokers with evidence of aberrant crypt foci (ACFs, precursors of colonic polyps) on outcome was examined [114]. After 30 days, it was found that individuals on $4 \mathrm{~g}$ of curcumin but not $2 \mathrm{~g}$ had a $40 \%$ reduction in the number of ACFs. Although previous work indicated the possibility that curcumin could inhibit the generation of prostaglandins, this was not confirmed in this study. It was postulated that curcumin derivatives present in plasma could have accounted for these findings. Nevertheless, in conjunction with findings from the FAP study [113] this indicates an important biological effect. As the upper limit of curcumin in dosage is not yet clear, this indicates that a higher dose may be required, or more importantly, investigation into the precise mechanism involved may be informative.

Thus, in concordance with in vitro and animal studies, human studies serve to validate the therapeutic potential of curcumin in IBD and bowel cancer, highlighting beneficial effects in prevention, maintenance, and even possible regression of disease.

\section{Newer Preparations of Curcumin}

Given the limitations of oral dosing with curcumin to achieve adequate plasma levels, a number of different approaches have been investigated. These include liposomes, nanogels, and nanoparticles (reviewed in [115]). This essentially results in improved solubilization because of the high surface area. Preliminary work seems to indicate that this is an effective approach for the treatment of cancer, as shown in several proof-of-concept studies. For example, a particular problem with cancer chemotherapy is the development of drug resistance, through drug efflux transporters such as MDR or ABCG2, which severely limit the amount of useful drug present to destroy tumor cells; it was possible to overcome this drug resistance utilizing curcumin nanoparticles, in breast cancer [116].

In a study looking at the pharmacokinetics of a curcumin nanoformulation, patients with osteosarcoma given 2 to $4 \mathrm{~g}$ of oral solid lipid curcumin were able to achieve up to $41 \mathrm{ng} / \mathrm{mL}$ serum concentrations within four hours [117]. From a safety prospective there were no adverse effects associated with this.

These observations clearly indicate an exciting development in improving curcumin delivery for systemic use, and with further refinements, may lead to better clinical responses in both inflammatory and neoplastic disorders.

\section{Conclusion}

In evaluating the role of curcumin in gastrointestinal disease, especially IBD and colon cancer, all aspects of its 
TABLE 2: Curcumin: a list of clinical studies in humans.

\begin{tabular}{|c|c|c|c|c|}
\hline Author/year & Phase & $\begin{array}{c}\text { Number of } \\
\text { patients }\end{array}$ & Dosage regimen & Findings \\
\hline \multicolumn{5}{|c|}{ Trials to assess safety and pharmacokinetics } \\
\hline Shoba et al., 1998 [25] & 1 & 10 & $\begin{array}{l}\text { Humans: } 2 \mathrm{~g} / \text { day } \\
\text { Mice: } 2 \mathrm{~g} / \mathrm{kg}\end{array}$ & $\begin{array}{l}\text { Piperine enhances the serum concentration, } \\
\text { absorption, and bioavailability of curcumin in } \\
\text { both rats and humans with no adverse effects }\end{array}$ \\
\hline Chen et al., 2001 [26] & 1 & 25 & $\begin{array}{l}500-12,000 \mathrm{mg} / \text { day } \times \\
90 \text { days }\end{array}$ & $\begin{array}{l}\text { Histologic improvement of precancerous lesions; } \\
\text { seen in } 1 \text { out of } 2 \text { patients with recently resected } \\
\text { bladder cancer, } 2 \text { out of } 7 \text { patients with oral } \\
\text { leukoplakia, } 1 \text { out of } 6 \text { patients with intestinal } \\
\text { metaplasia of the stomach, } 1 \text { out of } 4 \text { patients with } \\
\text { CIN, and } 2 \text { out of } 6 \text { patients with Bowen's disease }\end{array}$ \\
\hline Lao et al., 2006 [27] & 1 & 24 & $500-12,000 \mathrm{mg} /$ day & Curcumin is safe and well tolerated up to $12 \mathrm{~g} /$ day \\
\hline Author/year & Disease & $\begin{array}{c}\text { Number of } \\
\text { patients }\end{array}$ & Dosage regimen & Findings \\
\hline
\end{tabular}

Trials to assess efficacy in gastrointestinal disease (CRC and IBD)*

\begin{tabular}{|c|c|c|c|c|}
\hline Sharma et al., 2001 [28] & $\begin{array}{l}\text { Colorectal } \\
\text { cancer }\end{array}$ & 15 & $\begin{array}{l}36-180 \mathrm{mg} / \text { day } \times 120 \\
\text { days }\end{array}$ & $\begin{array}{l}\text { Radiologically stable disease in five patients for } \\
2-4 \text { months of treatment } \\
\text { Well tolerated, and dose-limiting toxicity was not } \\
\text { observed }\end{array}$ \\
\hline Sharma et al., 2004 [29] & $\begin{array}{l}\text { Colorectal } \\
\text { cancer }\end{array}$ & 15 & $\begin{array}{l}450-3600 \mathrm{mg} / \text { day } \times \\
120 \text { days }\end{array}$ & $\begin{array}{l}\text { Decrease in inducible PGE }(2) \text { production } \\
\text { Daily oral dose of } 3.6 \mathrm{~g} \text { of curcumin is advocated } \\
\text { for phase II evaluation in the prevention or } \\
\text { treatment of cancers outside the gastrointestinal } \\
\text { tract }\end{array}$ \\
\hline
\end{tabular}

\begin{tabular}{|c|c|c|c|c|}
\hline Garcea et al., 2004 [30] & $\begin{array}{l}\text { Liver } \\
\text { metastasis } \\
\text { in CRC }\end{array}$ & 43 & $\begin{array}{l}450-3600 \mathrm{mg} / \text { day } \times 7 \\
\text { day }\end{array}$ & Poor bioavailability following oral administration \\
\hline Garcea et al., 2005 [31] & CRC & 12 & $\begin{array}{l}450-3600 \mathrm{mg} / \text { day } \times 7 \\
\text { days }\end{array}$ & $\begin{array}{l}\text { Decreased M1G DNA adducts } \\
\text { COX-2 levels in malignant colorectal tissue not } \\
\text { affected by curcumin }\end{array}$ \\
\hline $\begin{array}{l}\text { Holt et al., } \\
2005 \text { [32] }\end{array}$ & IBD & 10 & $\begin{array}{l}550 \mathrm{mg} ; \times 2-3 / \text { day } \\
\times 60 \text { days }\end{array}$ & $\begin{array}{l}\text { All proctitis patients improved } \\
\text { Reduced concomitant medications in four of five } \\
\text { Crohn's disease patients } \\
\text { Lowered CDAI scores and sedimentation rates }\end{array}$ \\
\hline Hanai et al., 2006 [33] & $\begin{array}{l}\text { Ulcerative } \\
\text { colitis }\end{array}$ & 89 & $\begin{array}{l}2000 \mathrm{mg} / \text { day } \times 180 \\
\text { days }\end{array}$ & $\begin{array}{l}\text { Maintains remission } \\
\text { Improved both CAI (clinical activity index) and } \\
\text { EI (endoscopic index) that is } \\
\text { Reduced morbidity associated with UC }\end{array}$ \\
\hline
\end{tabular}

Ongoing trials (http://www.clinicaltrials.gov/)

Decrease in lymphocytic glutathione S-transferase activity

2-4 months of treatment

observed

Decrease in inducible PGE(2) production

for phase II evaluation in the prevention or

treatment of cancers outside the gastrointestina

Poor bioavailability following oral administration 
TABLE 2: Continued.

\begin{tabular}{|c|c|c|c|c|}
\hline Author/year & Phase & $\begin{array}{c}\text { Number of } \\
\text { patients }\end{array}$ & Dosage regimen & Findings \\
\hline $\begin{array}{l}\text { University of } \\
\text { Leicester/University } \\
\text { Hospitals Leicester, United } \\
\text { Kingdom [Est. date of } \\
\text { completion date: Jan, 2019] }\end{array}$ & $\begin{array}{l}\text { Colon } \\
\text { cancer }\end{array}$ & Recruiting & & $\begin{array}{l}\text { Phase I/II a study combining curcumin } \\
\text { (curcumin C3-complex, sabinsa) with standard } \\
\text { care FOLFOX chemotherapy in patients with } \\
\text { inoperable colorectal cancer } \\
\text { (i) Will focus on safety and tolerability } \\
\text { (ii) Secondary measurements include efficacy } \\
\text { supported by biomarker analysis }\end{array}$ \\
\hline $\begin{array}{l}\text { University of California, } \\
\text { Irvine, US [Est date of } \\
\text { completion: Dec, 2012] }\end{array}$ & $\begin{array}{l}\text { Colon } \\
\text { cancer }\end{array}$ & Estimated: 48 & & $\begin{array}{l}\text { Phase II a trial of curcumin among patients with } \\
\text { prevalent subclinical neoplastic lesions (aberrant } \\
\text { crypt Foci): } \\
\text { (i) Will determine mean percentage change in } \\
\text { PGE2 within aberrant crypt foci (ACF) from } \\
\text { baseline to } 30 \text { days after treatment with } \\
\text { curcumin in current smokers. }\end{array}$ \\
\hline $\begin{array}{l}\text { University of North } \\
\text { Carolina, Chapel Hill, US } \\
\text { [Est. date of completion: } \\
\text { March, 2012] }\end{array}$ & & & $\begin{array}{l}4 \text { grams curcumin C3 } \\
\text { tablet daily } \times 30 \text { days }\end{array}$ & $\begin{array}{l}\text { Chemoprevention of colorectal neoplasia: } \\
\text { (i) Use of microarray analysis to identify genes } \\
\text { that are modified by curcumin that could be } \\
\text { used as biomarkers in future chemoprevention } \\
\text { studies } \\
\text { (ii) Will also evaluate tolerability and toxicity }\end{array}$ \\
\hline
\end{tabular}

* Patient trials have also demonstrated clinical benefit in: rheumatoid arthritis, psoriasis, postoperative inflammation, chronic anterior uveitis and orbital inflammatory pseudo-tumours, irritable bowel syndrome, tropical pancreatitis, gall bladder and biliary motility, gastric ulceration, and familial adenomatous polyposis coli.

use need to be considered. As outlined by countless in vitro and animal studies, curcumin has proven beneficial in attenuating/ameliorating biochemical, histological, and symptomatic disease parameters. Moreover, its pharmacodynamic profile as a low toxicity alternative places it on a pedestal distinct from more traditional treatments such as 5 -aminosalicylates or corticosteroid therapy whose expense and/or adverse reaction profiles render them problematic [118]. The limitations of existing medicines in maintaining remission of these disorders can be a product of altered forms of immune dysregulation which remain refractory to current therapy. For example, anti-TNF $\alpha$ antibody therapy targets TNF $\alpha$ as the prime instigator of inflammation. However, as demonstrated in previous animal studies, immune alteration in IBD proves multidimensional, responsive to a certain form of treatment in some cases and not in others. Curcumin may favorably alter the "inflammatory" balance, and whether it is used as a synergistic supplement or a stand-alone therapy, or whether or not new formulations are used, the realization of a therapeutic potential (for curcumin) provides a new paradigm for gastrointestinal disease management.

Epidemiological analysis of IBD emphasizes a distinct difference between incidence and prevalence of IBD in the West and in Asia, the latter exhibiting a relatively lower rate of both [119]. However, across Asia the incidence and prevalence of IBD have increased rapidly over the last two to four decades, these changes occurring concurrently with increased westernization of their diet. With curcumin being such a fundamental ingredient in Asian cuisine, it is not unreasonable to invoke this as a prime etiological agent contributing to the decreased prevalence of "western gastrointestinal disease" in the region, necessitating additional human studies to confirm. However, human studies are hampered by its inadequate bioavailability, attributed to poor aqueous solubility of the agent [120]. To counter this, as discussed above, new approaches to overcome curcumin's low bioavailability are being developed in the form of liposomal preparations, nanoparticle-based systems, and even adjuncts such as piperine augmenting curcumin's accessibility [25]. Thus, improved preparations for use in human patients together with the use of larger cohorts will act to validate preexisting notions regarding curcumin's utility and pave the way for greater understanding of this exotic ingredient's algorithmic role in future treatment of patients with IBD, colon cancer, and various other gastrointestinal ailments.

\section{Conflict of Interests}

There is no conflict of interests to disclose for either author.

\section{References}

[1] R. S. Sandler, J. E. Everhart, M. Donowitz et al., "The burden of selected digestive diseases in the United States," Gastroenterology, vol. 122, no. 5, pp. 1500-1511, 2002.

[2] F. Kamangar, G. M. Dores, and W. F. Anderson, "Patterns of cancer incidence, mortality, and prevalence across five continents: defining priorities to reduce cancer disparities in different geographic regions of the world," Journal of Clinical Oncology, vol. 24, no. 14, pp. 2137-2150, 2006.

[3] D. M. Parkin, F. Bray, J. Ferlay, and P. Pisani, "Global cancer statistics, 2002," CA Cancer Journal for Clinicians, vol. 55, no. 2, pp. 74-108, 2005. 
[4] J. Xie and S. H. Itzkowitz, "Cancer in inflammatory bowel disease," World Journal of Gastroenterology, vol. 14, no. 3, pp. 378-389, 2008.

[5] D. C. Baumgart and W. J. Sandborn, "Inflammatory bowel disease: clinical aspects and established and evolving therapies," The Lancet, vol. 369, no. 9573, pp. 1641-1657, 2007.

[6] S. H. Itzkowitz and X. Yio, "Inflammation and cancer-IV. Colorectal cancer in inflammatory bowel disease: the role of inflammation," American Journal of Physiology, vol. 287, no. 1, pp. G7-G17, 2004.

[7] S. R. Targan, S. B. Hanauer, S. J. H. van Deventer et al., "A shortterm study of chimeric monoclonal antibody cA2 to tumor necrosis factor $\alpha$ for Crohn's disease," The New England Journal of Medicine, vol. 337, no. 15, pp. 1029-1035, 1997.

[8] K. Sugimoto, H. Hanai, K. Tozawa et al., "Curcumin prevents and ameliorates trinitrobenzene sulfonic acid-induced colitis in mice," Gastroenterology, vol. 123, no. 6, pp. 1912-1922, 2002.

[9] S. Perkins, R. D. Verschoyle, K. Hill et al., "Chemopreventive efficacy and pharmacokinetics of curcumin in the $\mathrm{min} /+$ mouse, a model of familial adenomatous polyposis," Cancer Epidemiology, Biomarkers \& Prevention, vol. 11, pp. 535-540, 2002.

[10] S. Perkins, A. R. Clarke, W. Steward, and A. Gescher, "Agerelated difference in susceptibility of Apc(Min/+) mice towards the chemopreventive efficacy of dietary aspirin and curcumin," British Journal of Cancer, vol. 88, pp. 1480-1483, 2003.

[11] A. Ukil, S. Maity, S. Karmakar, N. Datta, J. R. Vedasiromoni, and P. K. Das, "Curcumin, the major component of food flavour turmeric, reduces mucosal injury in trinitrobenzene sulphonic acid-induced colitis," British Journal of Pharmacology, vol. 139, no. 2, pp. 209-218, 2003.

[12] B. Salh, K. Assi, V. Templeman et al., "Curcumin attenuates DNB-induced murine colitis," American Journal of Physiology, vol. 285, no. 1, pp. G235-G243, 2003.

[13] Y. T. Jian, G. F. Mai, J. D. Wang, Y. L. Zhang, R. C. Luo, and Y. X. Fang, "Preventive and therapeutic effects of NF-kappaB inhibitor curcumin in rats colitis induced by trinitrobenzene sulfonic acid," World Journal of Gastroenterology, vol. 11, no. 12, pp. 1747-1752, 2005.

[14] H. Jiang, C.-S. Deng, M. Zhang, and J. Xia, "Curcuminattenuated trinitrobenzene sulphonic acid induces chronic colitis by inhibiting expression of cyclooxygenase-2," World Journal of Gastroenterology, vol. 12, no. 24, pp. 3848-3853, 2006.

[15] M. Zhang, C. S. Deng, J. J. Zheng, and J. Xia, "Curcumin regulated shift from Th1 to Th2 in trinitrobenzene sulphonic acid-induced chronic colitis," Acta Pharmacologica Sinica, vol. 27, no. 8, pp. 1071-1077, 2006.

[16] M. V. Venkataranganna, M. Rafiq, S. Gopumadhavan, G. Peer, U. V. Babu, and S. K. Mitra, "NCB-02 (standardized Curcumin preparation) protects dinitrocholorobenzene-induced colitis through down-regulation of NFא-B and iNOS," World Journal of Gastroenterology, vol. 13, no. 7, pp. 1103-1107, 2007.

[17] L. Camacho-Barquero, I. Villegas, J. M. Sánchez-Calvo et al., "Curcumin, a Curcuma longa constituent, acts on MAPK p38 pathway modulating COX-2 and iNOS expression in chronic experimental colitis," International Immunopharmacology, vol. 7, no. 3, pp. 333-342, 2007.

[18] L. Martelli, E. Ragazzi, F. Di Mario et al., "A potential role for the vanilloid receptor TRPV1 in the therapeutic effect of curcumin in dinitrobenzene sulphonic acid-induced colitis in mice," Neurogastroenterology and Motility, vol. 19, no. 8, pp. 668-674, 2007.
[19] Y. Deguchi, A. Andoh, O. Inatomi et al., "Curcumin prevents the development of dextran sulfate sodium (DSS)-induced experimental colitis," Digestive Diseases and Sciences, vol. 52, no. 11, pp. 2993-2998, 2007.

[20] C. Billerey-Larmonier, J. K. Uno, N. Larmonier et al., "Protective effects of dietary curcumin in mouse model of chemically induced colitis are strain dependent," Inflammatory Bowel Diseases, vol. 14, no. 6, pp. 780-793, 2008.

[21] C. B. Larmonier, J. K. Uno, K. M. Lee et al., "Limited effects of dietary curcumin on Th-1 driven colitis in IL-10 deficient mice suggest an IL-10-dependent mechanism of protection," American Journal of Physiology, vol. 295, no. 5, pp. G1079-G1091, 2008.

[22] K. Nones, Y. E. M. Dommels, S. Martell et al., "The effects of dietary curcumin and rutin on colonic inflammation and gene expression in multidrug resistance gene-deficient (mdrla/-) mice, a model of inflammatory bowel diseases," The British Journal of Nutrition, vol. 101, no. 2, pp. 169-181, 2009.

[23] A. Lubbad, M. A. Oriowo, and I. Khan, "Curcumin attenuates inflammation through inhibition of TLR-4 receptor in experimental colitis," Molecular and Cellular Biochemistry, vol. 322, no. 1-2, pp. 127-135, 2009.

[24] Q. Jia, I. Ivanov, Z. Z. Zlatev et al., "Dietary fish oil and curcumin combine to modulate colonic cytokinetics and gene expression in dextran sodium sulphate-treated mice," The British Journal of Nutrition, vol. 106, no. 4, pp. 519-529, 2011.

[25] G. Shoba, D. Joy, T. Joseph, M. Majeed, R. Rajendran, and P. S. S. R. Srinivas, "Influence of piperine on the pharmacokinetics of curcumin in animals and human volunteers," Planta Medica, vol. 64, no. 4, pp. 353-356, 1998.

[26] A. L. Chen, C. H. Hsu, J. K. Lin et al., "Phase I clinical trial of curcumin, a chemopreventive agent, in patients with high-risk or pre-malignant lesions," Anticancer Research, vol. 21, no. 4, pp. 2895-2900, 2001.

[27] C. D. Lao, M. T. Ruffin, D. Normolle et al., "Dose escalation of a curcuminoid formulation," BMC Complementary and Alternative Medicine, vol. 6, article 10, 2006.

[28] R. A. Sharma, H. R. McLelland, K. A. Hill et al., "Pharmacodynamic and pharmacokinetic study of oral Curcuma extract in patients with colorectal cancer," Clinical Cancer Research, vol. 7, no. 7, pp. 1894-1900, 2001.

[29] R. A. Sharma, S. A. Euden, S. L. Platton et al., "Phase I clinical trial of oral curcumin: biomarkers of systemic activity and compliance," Clinical Cancer Research, vol. 10, no. 20, pp. 6847-6854, 2004.

[30] G. Garcea, D. J. L. Jones, R. Singh et al., "Detection of curcumin and its metabolites in hepatic tissue and portal blood of patients following oral administration," British Journal of Cancer, vol. 90, no. 5, pp. 1011-1015, 2004.

[31] G. Garcea, D. P. Berry, D. J. L. Jones et al., "Consumption of the putative chemopreventive agent curcumin by cancer patients: assessment of curcumin levels in the colorectum and their pharmacodynamic consequences," Cancer Epidemiology Biomarkers and Prevention, vol. 14, no. 1, pp. 120-125, 2005.

[32] P. R. Holt, S. Katz, and R. Kirshoff, "Curcumin therapy in inflammatory bowel disease: a pilot study," Digestive Diseases and Sciences, vol. 50, no. 11, pp. 2191-2193, 2005.

[33] H. Hanai, T. Iida, K. Takeuchi et al., "Curcumin maintenance therapy for ulcerative colitis: randomized, multicenter, doubleblind, placebo-controlled trial," Clinical Gastroenterology and Hepatology, vol. 4, no. 12, pp. 1502-1506, 2006. 
[34] P. M. Barnes, B. Bloom, and R. L. Nahin, "Complementary and alternative medicine use among adults and children: United States, 2007," National Health Statistics Reports, no. 12, pp. 1-23, 2008.

[35] R. J. Hilsden, M. J. Verhoef, H. Rasmussen, A. Porcino, and J. C. C. Debruyn, "Use of complementary and alternative medicine by patients with inflammatory bowel disease," Inflammatory Bowel Diseases, vol. 17, no. 2, pp. 655-662, 2011.

[36] K. L. Goh and S. D. Xiao, "Inflammatory bowel disease: a survey of the epidemiology in Asia," Journal of Digestive Diseases, vol. 10, no. 1, pp. 1-6, 2009.

[37] S. M. Montgomery, D. L. Morris, R. E. Pounder, and A. J. Wakefield, "Asian ethnic origin and the risk of inflammatory bowel disease," European Journal of Gastroenterology and Hepatology, vol. 11, no. 5, pp. 543-546, 1999.

[38] B. K. Mangat, C. Evaschen, T. Lee, E. M. Yoshida, and B. Salh, "Ethnic variation in the annual rates of adult inflammatory bowel disease in hospitalized patients in Vancouver, British Columbia," Canadian Journal of Gastroenterology, vol. 25, no. 2, pp. 73-77, 2011.

[39] R. Virk, S. Gill, E. Yoshida, S. Radley, and B. Salh, "Racial differences in the incidence of colorectal cancer," Canadian Journal of Gastroenterology, vol. 24, no. 1, pp. 47-51, 2010.

[40] H. P. T. Ammon and M. A. Wahl, "Pharmacology of Curcuma longa," Planta Medica, vol. 57, no. 1, pp. 1-7, 1991.

[41] P. Anand, S. G. Thomas, A. B. Kunnumakkara et al., "Biological activities of curcumin and its analogues (Congeners) made by man and mother nature," Biochemical Pharmacology, vol. 76, no. 11, pp. 1590-1611, 2008.

[42] S. K. Sandur, A. Deorukhkar, M. K. Pandey et al., "Curcumin modulates the radiosensitivity of colorectal cancer cells by suppressing constitutive and inducible nf-kappab activity," International Journal of Radiation Oncology Biology Physics, vol. 75, no. 2, pp. 534-542, 2009.

[43] S. Somasundaram, N. A. Edmund, D. T. Moore, G. W. Small, Y. Y. Shi, and R. Z. Orlowski, "Dietary curcumin inhibits chemotherapy-induced apoptosis in models of human breast cancer," Cancer Research, vol. 62, no. 13, pp. 3868-3875, 2002.

[44] N. Chainani-Wu, "Safety and anti-inflammatory activity of curcumin: a component of tumeric (Curcuma longa)," Journal of Alternative and Complementary Medicine, vol. 9, no. 1, pp. 161-168, 2003.

[45] M. Nagabhushan and S. V. Bhide, "Nonmutagenicity of curcumin and its antimutagenic action versus chili and capsaicin," Nutrition and Cancer, vol. 8, no. 3, pp. 201-210, 1986.

[46] P. Anand, A. B. Kunnumakkara, R. A. Newman, and B. B. Aggarwal, "Bioavailability of curcumin: problems and promises," Molecular Pharmaceutics, vol. 4, no. 6, pp. 807-818, 2007.

[47] S. L. Thomas, D. Zhong, W. Zhou et al., "EF24, a novel curcumin analog, disrupts the microtubule cytoskeleton and inhibits HIF1," Cell Cycle, vol. 7, no. 15, pp. 2409-2417, 2008.

[48] B. T. Kurien, A. Singh, H. Matsumoto, and R. H. Scofield, "Improving the solubility and pharmacological efficacy of curcumin by heat treatment," Assay and Drug Development Technologies, vol. 5, no. 4, pp. 567-576, 2007.

[49] S. K. Sandur, M. K. Pandey, B. Sung et al., "Curcumin, demethoxycurcumin, bisdemethoxycurcumin, tetrahydrocurcumin and turmerones differentially regulate anti-inflammatory and anti-proliferative responses through a ROS-independent mechanism," Carcinogenesis, vol. 28, no. 8, pp. 1765-1773, 2007.
[50] S. C. Gupta, S. Prasad, J. H. Kim et al., "Multitargeting by curcumin as revealed by molecular interaction studies," Natural Product Reports, vol. 28, pp. 1937-1955, 2011.

[51] S. Ali, A. Ahmad, S. Banerjee et al., "Gemcitabine sensitivity can be induced in pancreatic cancer cells through modulation of miR-200 and miR-21 expression by curcumin or its analogue CDF," Cancer Research, vol. 70, no. 9, pp. 3606-3617, 2010.

[52] B. B. Aggarwal, S. Shishodia, S. K. Sandur, M. K. Pandey, and G. Sethi, "Inflammation and cancer: how hot is the link?" Biochemical Pharmacology, vol. 72, no. 11, pp. 1605-1621, 2006.

[53] S. Singh and B. B. Aggarwal, "Activation of transcription factor nf-kappa b is suppressed by curcumin (diferuloylmethane)," The Journal of Biological Chemistry, vol. 270, pp. 24995-25000, 1995.

[54] C. Jobin, C. A. Bradham, M. P. Russo et al., "Curcumin blocks cytokine-mediated NF- $\kappa$ B activation and proinflammatory gene expression by inhibiting inhibitory factor I- $\kappa$ B kinase activity," Journal of Immunology, vol. 163, no. 6, pp. 3474-3483, 1999.

[55] S. Aggarwal, H. Ichikawa, Y. Takada, S. K. Sandur, S. Shishodia, and B. B. Aggarwal, "Curcumin (diferuloylmethane) downregulates expression of cell proliferation and antiapoptotic and metastatic gene products through suppression of $\mathrm{I} \kappa \mathrm{B} \alpha$ kinase and Akt activation," Molecular Pharmacology, vol. 69, no. 1, pp. 195-206, 2006.

[56] J. H. Cho, "The genetics and immunopathogenesis of inflammatory bowel disease," Nature Reviews Immunology, vol. 8, no. 6, pp. 458-466, 2008.

[57] S. Huang, L. Zhao, K. Kim, S. L. Dong, and D. H. Hwang, "Inhibition of Nod2 signaling and target gene expression by curcumin," Molecular Pharmacology, vol. 74, no. 1, pp. 274-281, 2008.

[58] S. Kreuz, D. Siegmund, P. Scheurich, and H. Wajant, "NF- $\kappa$ B inducers upregulate cFLIP, a cycloheximide-sensitive inhibitor of death receptor signaling," Molecular and Cellular Biology, vol. 21, no. 12, pp. 3964-3973, 2001.

[59] M. Tamatani, Y. H. Che, H. Matsuzaki et al., "Tumor necrosis factor induces $\mathrm{Bcl}-2$ and $\mathrm{Bcl}-\mathrm{x}$ expression through $\mathrm{NF} \kappa \mathrm{B}$ activation in primary hippocampal neurons," The Journal of Biological Chemistry, vol. 274, no. 13, pp. 8531-8538, 1999.

[60] W. X. Zong, L. C. Edelstein, C. Chen, J. Bash, and C. Gélinas, "The prosurvival Bcl-2 homolog Bfl-1/A1 is a direct transcriptional target of NF- $\kappa \mathrm{B}$ that blocks TNF $\alpha$-induced apoptosis," Genes and Development, vol. 13, no. 4, pp. 382-387, 1999.

[61] C. Stehlik, R. de Martin, I. Kumabashiri, J. A. Schmid, B. R. Binder, and J. Lipp, "Nuclear factor (NF)- $\kappa$ B-regulated Xchromosome-linked iap gene expression protects endothelial cells from tumor necrosis factor $\alpha$-induced apoptosis," Journal of Experimental Medicine, vol. 188, no. 1, pp. 211-216, 1998.

[62] C. Y. Wang, M. W. Mayo, R. G. Korneluk, D. V. Goeddel, and A. S. Baldwin, "NF- $\kappa$ B antiapoptosis: induction of TRAF1 and TRAF2 and c-IAP1 and c- IAP2 to suppress caspase- 8 activation," Science, vol. 281, no. 5383, pp. 1680-1683, 1998.

[63] L. Zhu, S. Fukuda, G. Cordis, D. K. Das, and N. Maulik, "Antiapoptotic protein survivin plays a significant role in tubular morphogenesis of human coronary arteriolar endothelial cells by hypoxic preconditioning," FEBS Letters, vol. 508, no. 3, pp. 369-374, 2001.

[64] A. B. Kunnumakkara, P. Diagaradjane, P. Anand et al., "Curcumin sensitizes human colorectal cancer to capecitabine by modulation of cyclin D1, COX-2, MMP-9, VEGF and CXCR4 
expression in an orthotopic mouse model," International Journal of Cancer, vol. 125, no. 9, pp. 2187-2197, 2009.

[65] M. Moussavi, K. Assi, A. Gómez-Muñoz, and B. Salh, "Curcumin mediates ceramide generation via the de novo pathway in colon cancer cells," Carcinogenesis, vol. 27, no. 8, pp. 1636-1644, 2006.

[66] Y. Cheng, A. Kozubek, L. Ohlsson, B. Sternby, and R. D. Duan, "Curcumin decreases acid sphingomyelinase activity in colon cancer caco-2 cells," Planta Medica, vol. 73, no. 8, pp. 725-730, 2007.

[67] J. F. Schmedtje Jr., Y. S. Ji, W. L. Liu, R. N. DuBois, and M. S. Runge, "Hypoxia induces cyclooxygenase-2 via the NF- $\kappa \mathrm{B}$ p65 transcription factor in human vascular endothelial cells," The Journal of Biological Chemistry, vol. 272, no. 1, pp. 601-608, 1997.

[68] M. Hinz, D. Krappmann, A. Eichten, A. Heder, C. Scheidereit, and M. Strauss, "NF- $\kappa$ B function in growth control: regulation of cyclin D1 expression and G0/G1-to-S-phase transition," Molecular and Cellular Biology, vol. 19, no. 4, pp. 2690-2698, 1999.

[69] M. P. Duyao, A. J. Buckler, and G. E. Sonenshein, "Interaction of an NF- $\kappa$ B-like factor with a site upstream of the c-myc promoter," Proceedings of the National Academy of Sciences of the United States of America, vol. 87, no. 12, pp. 4727-4731, 1990.

[70] D. G. Binion, M. F. Otterson, and P. Rafiee, "Curcumin inhibits VEGF-mediated angiogenesis in human intestinal microvascular endothelial cells through COX-2 and MAPK inhibition," Gut, vol. 57, no. 11, pp. 1509-1517, 2008.

[71] T. Yokoo and M. Kitamura, "Dual regulation of IL- $1 \beta$-mediated matrix metalloproteinase- 9 expression in mesangial cells by NF-KB and AP-1," American Journal of Physiology, vol. 270, no. 1, pp. F123-F130, 1996.

[72] G. Helbig, K. W. Christopherson, P. Bhat-Nakshatri et al., "NF$\kappa \mathrm{B}$ promotes breast cancer cell migration and metastasis by inducing the expression of the chemokine receptor CXCR4," The Journal of Biological Chemistry, vol. 278, no. 24, pp. 21631-21638, 2003.

[73] D. Šošić, J. A. Richardson, K. Yu, D. M. Ornitz, and E. N. Olson, "Twist regulates cytokine gene expression through a negative feedback loop that represses NF- $\kappa$ B activity," Cell, vol. 112, no. 2, pp. 169-180, 2003.

[74] S. M. Plummer, K. A. Holloway, M. M. Manson et al., "Inhibition of cyclo-oxygenase 2 expression in colon cells by the chemopreventive agent curcumin involves inhibition of NF- $\kappa \mathrm{B}$ activation via the NIK/IKK signalling complex," Oncogene, vol. 18, no. 44, pp. 6013-6020, 1999.

[75] L. Adam, A. Mazumdar, T. Sharma, T. R. Jones, and R. Kumar, "A three-dimensional and temporo-spatial model to study invasiveness of cancer cells by heregulin and prostaglandin E21," Cancer Research, vol. 61, no. 1, pp. 81-87, 2001.

[76] H. Sheng, J. Shao, M. K. Washington, and R. N. DuBois, "Prostaglandin e2 increases growth and motility of colorectal carcinoma cells," The Journal of Biological Chemistry, vol. 276, no. 21, pp. 18075-18081, 2001.

[77] W. S. Chen, S. J. Wei, J. M. Liu, M. Hsiao, J. Kou-Lin, and W. K. Yang, "Tumor invasiveness and liver metastasis of colon cancer cells correlated with cyclooxygenase-2 (cox-2) expression and inhibited by a cox-2-selective inhibitor, etodolac," International Journal of Cancer, vol. 91, pp. 894-899, 2001.
[78] M. J. Thun, M. M. Namboodiri, and C. W. Heath Jr., "Aspirin use and reduced risk of fatal colon cancer," The New England Journal of Medicine, vol. 325, no. 23, pp. 1593-1596, 1991.

[79] M. J. Thun, S. J. Henley, and C. Patrono, "Nonsteroidal antiinflammatory drugs as anticancer agents: mechanistic, pharmacologic, and clinical issues," Journal of the National Cancer Institute, vol. 94, no. 4, pp. 252-266, 2002.

[80] J. L. Arbiser, N. Klauber, R. Rohan et al., "Curcumin is an in vivo inhibitor of angiogenesis," Molecular Medicine, vol. 4, no. 6, pp. 376-383, 1998.

[81] D. G. Binion, J. Heidemann, M. S. Li, V. M. Nelson, M. F. Otterson, and P. Rafiee, "Vascular cell adhesion molecule-1 expression in human intestinal microvascular endothelial cells is regulated by PI 3-kinase/Akt/MAPK/NF- $\kappa \mathrm{B}$ : inhibitory role of curcumin," American Journal of Physiology, vol. 297, no. 2, pp. G259-G268, 2009.

[82] D. Thaloor, A. K. Singh, G. S. Sidhu, P. V. Prasad, H. K. Kleinman, and R. K. Maheshwari, "Inhibition of angiogenic differentiation of human umbilical vein endothelial cells by curcumin," Cell Growth and Differentiation, vol. 9, no. 4, pp. 305-312, 1998

[83] M. K. Bae, S. H. Kim, J. W. Jeong et al., "Curcumin inhibits hypoxia-induced angiogenesis via down-regulation of HIF-1," Oncology Reports, vol. 15, no. 6, pp. 1557-1562, 2006.

[84] J. S. Shim, J. H. Kim, H. Y. Cho et al., "Irreversible inhibition of CD13/aminopeptidase $\mathrm{N}$ by the antiangiogenic agent curcumin," Chemistry and Biology, vol. 10, no. 8, pp. 695-704, 2003.

[85] S. Yodkeeree, W. Chaiwangyen, S. Garbisa, and P. Limtrakul, "Curcumin, demethoxycurcumin and bisdemethoxycurcumin differentially inhibit cancer cell invasion through the downregulation of MMPs and uPA," Journal of Nutritional Biochemistry, vol. 20, no. 2, pp. 87-95, 2009.

[86] J. Epstein, G. Docena, T. T. MacDonald, and I. R. Sanderson, "Curcumin suppresses p38 mitogen-activated protein kinase activation, reduces IL- $1 \beta$ and matrix metalloproteinase- 3 and enhances IL-10 in the mucosa of children and adults with inflammatory bowel disease," British Journal of Nutrition, vol. 103, no. 6, pp. 824-832, 2010.

[87] P. J. Moos, K. Edes, J. E. Mullally, and F. A. Fitzpatrick, "Curcumin impairs tumor suppressor p53 function in colon cancer cells," Carcinogenesis, vol. 25, no. 9, pp. 1611-1617, 2004.

[88] S. S. Han, S. T. Chung, D. A. Robertson, D. Ranjan, and S. Bondada, "Curcumin causes the growth arrest and apoptosis of B cell lymphoma by downregulation of egr-1, C-myc, Bcl$\mathrm{X}(\mathrm{l}), \mathrm{NF}-\kappa \mathrm{B}$, and p53," Clinical Immunology, vol. 93, no. 2, pp. 152-161, 1999.

[89] G. Song, Y. B. Mao, Q. F. Cai, L. M. Yao, G. L. Ouyang, and S. D. Bao, "Curcumin induces human HT-29 colon adenocarcinoma cell apoptosis by activating p53 and regulating apoptosis-related protein expression," Brazilian Journal of Medical and Biological Research, vol. 38, no. 12, pp. 1791-1798, 2005.

[90] T. Choudhuri, S. Pal, T. Das, and G. Sa, "Curcumin selectively induces apoptosis in deregulated cyclin D1-expressed cells at G2 phase of cell cycle in a p53-dependent manner," The Journal of Biological Chemistry, vol. 280, no. 20, pp. 20059-20068, 2005.

[91] G. P. Collett and F. C. Campbell, "Curcumin induces c-jun Nterminal kinase-dependent apoptosis in HCT116 human colon cancer cells," Carcinogenesis, vol. 25, no. 11, pp. 2183-2189, 2004. 
[92] M. Hu, Q. Du, I. Vancurova et al., "Proapoptotic effect of curcumin on human neutrophils: activation of the p38 mitogenactivated protein kinase pathway," Critical Care Medicine, vol. 33, no. 11, pp. 2571-2578, 2005.

[93] A. Chen and J. Xu, "Activation of PPAR $\gamma$ by curcumin inhibits Moser cell growth and mediates suppression of gene expression of cyclin D1 and EGFR," American Journal of Physiology, vol. 288, no. 3, pp. G447-G456, 2005.

[94] C. V. Rao, B. Simi, and B. S. Reddy, "Inhibition by dietary curcumin of azoxymethane-induced ornithine decarboxylase, tyrosine protein kinase, arachidonic acid metabolism and aberrant crypt foci formation in the rat colon," Carcinogenesis, vol. 14, no. 11, pp. 2219-2225, 1993.

[95] J. M. Kim, S. Araki, D. J. Kim et al., "Chemopreventive effects of carotenoids and curcumins on mouse colon carcinogenesis after 1,2-dimethylhydrazine initiation," Carcinogenesis, vol. 19, no. 1, pp. 81-85, 1998.

[96] B. Joe and B. R. Lokesh, "Dietary n-3 fatty acids, curcumin and capsaicin lower the release of lysosomal enzymes and eicosanoids in rat peritoneal macrophages," Molecular and Cellular Biochemistry, vol. 203, no. 1-2, pp. 153-161, 2000.

[97] D. J. B. Marks and A. W. Segal, "Innate immunity in inflammatory bowel disease: a disease hypothesis," Journal of Pathology, vol. 214, no. 2, pp. 260-266, 2008.

[98] C. B. Larmonier, M. T. Midura-Kiela, R. Ramalingam et al., "Modulation of neutrophil motility by curcumin: implications for inflammatory bowel disease," Inflammatory Bowel Diseases, vol. 17, no. 2, pp. 503-515, 2011.

[99] I. Villegas, S. Sánchez-Fidalgo, and C. A. de la Lastra, "Chemopreventive effect of dietary curcumin on inflammation-induced colorectal carcinogenesis in mice," Molecular Nutrition and Food Research, vol. 55, no. 2, pp. 259-267, 2011.

[100] E. A. Murphy, J. M. Davis, J. L. McClellan, B. T. Gordon, and M. D. Carmichael, "Curcumin's effect on intestinal inflammation and tumorigenesis in the ApcMin/+ mouse," Journal of Interferon and Cytokine Research, vol. 31, no. 2, pp. 219-226, 2011.

[101] M. Kubota, M. Shimizu, H. Sakai et al., "Preventive effects of curcumin on the development of azoxymethane-induced colonic preneoplastic lesions in male $\mathrm{c} 57 \mathrm{bl} / \mathrm{ksj}-\mathrm{db} / \mathrm{db}$ obese mice," Nutrition and Cancer, vol. 64, no. 1, pp. 72-79, 2012.

[102] K. Assi and B. Salh, "Curcumin reduces neoplasms in a model of colitis-associated cancer through effects on ILK, b-catenin, cyclin D, NF-kB and Akt," Gastroenterology A412, 2011.

[103] B. Chandran and A. Goel, "A randomized, pilot study to assess the efficacy and safety of curcumin in patients with active rheumatoid arthritis," Phytotherapy Research. In press.

[104] D. Banji, J. Pinnapureddy, O. J. F. Banji, A. Saidulu, and M. S. Hayath, "Synergistic activity of curcumin with methotrexate in ameliorating Freund's Complete Adjuvant induced arthritis with reduced hepatotoxicity in experimental animals," European Journal of Pharmacology, vol. 668, pp. 293-298, 2011.

[105] M. C. Y. Heng, M. K. Song, J. Harker, and M. K. Heng, "Druginduced suppression of phosphorylase kinase activity correlates with resolution of psoriasis as assessed by clinical, histological and immunohistochemical parameters," British Journal of Dermatology, vol. 143, no. 5, pp. 937-949, 2000.

[106] R. R. Satoskar, S. J. Shah, and S. G. Shenoy, "Evaluation of anti-inflammatory property of curcumin (diferuloyl methane) in patients with postoperative inflammation," International Journal of Clinical Pharmacology Therapy and Toxicology, vol. 24, no. 12, pp. 651-654, 1986.
[107] B. Lal, A. K. Kapoor, O. P. Asthana et al., "Efficacy of curcumin in the management of chronic anterior uveitis," Phytotherapy Research, vol. 13, pp. 318-322, 1999.

[108] B. Lal, A. K. Kapoor, P. K. Agrawal, O. P. Asthana, and R. C. Srimal, "Role of curcumin in idiopathic inflammatory orbital pseudotumours," Phytotherapy Research, vol. 14, pp. 443-447, 2000.

[109] R. Bundy, A. F. Walker, R. W. Middleton, and J. Booth, "Turmeric extract may improve irritable bowel syndrome symptomology in otherwise healthy adults: a pilot study," Journal of Alternative and Complementary Medicine, vol. 10, no. 6, pp. 1015-1018, 2004.

[110] S. Durgaprasad, C. G. Pai, Vasanthkumar, J. F. Alvres, and S. Namitha, "A pilot study of the antioxidant effect of curcumin in tropical pancreatitis," Indian Journal of Medical Research, vol. 122, no. 4, pp. 315-318, 2005.

[111] C. Niederau and E. Göpfert, "The effect of extracts from Schollkraut and Curcuma on upper abdominal pain due to dysfunction of the biliary system: results of a placebo- controlled, double-blind study," Medizinische Klinik, vol. 94, no. 8, pp. 425-430, 1999.

[112] C. Prucksunand, B. Indrasukhsri, M. Leethochawalit, and K. Hungspreugs, "Phase II clinical trial on effect of the long turmeric (Curcuma longa Linn) on healing of peptic ulcer," Southeast Asian Journal of Tropical Medicine and Public Health, vol. 32, no. 1, pp. 208-215, 2001.

[113] M. Cruz-Correa, D. A. Shoskes, P. Sanchez et al., "Combination treatment with curcumin and quercetin of adenomas in familial adenomatous polyposis," Clinical Gastroenterology and Hepatology, vol. 4, no. 8, pp. 1035-1038, 2006.

[114] R. E. Carroll, R. V. Benya, D. K. Turgeon et al., "Phase IIa clinical trial of curcumin for the prevention of colorectal neoplasia," Cancer Prevention Research, vol. 4, no. 3, pp. 354-364, 2011.

[115] M. M. Yallapu, M. Jaggi, and S. C. Chauhan, "Curcumin nanoformulations: a future nanomedicine for cancer," Drug Discovery Today, vol. 17, no. 1-2, pp. 71-80, 2012.

[116] Y. Um, S. Cho, H. B. Woo et al., "Synthesis of curcumin mimics with multidrug resistance reversal activities," Bioorganic and Medicinal Chemistry, vol. 16, no. 7, pp. 3608-3615, 2008.

[117] V. S. Gota, G. B. Maru, T. G. Soni, T. R. Gandhi, N. Kochar, and M. G. Agarwal, "Safety and pharmacokinetics of a solid lipid curcumin particle formulation in osteosarcoma patients and healthy volunteers," Journal of Agricultural and Food Chemistry, vol. 58, no. 4, pp. 2095-2099, 2010.

[118] S. B. Hanauer and G. Stathopoulos, "Risk-benefit assessment of drugs used in the treatment of inflammatory bowel disease," Drug Safety, vol. 6, no. 3, pp. 192-219, 1991.

[119] L. Prideaux, M. A. Kamm, P. P. De Cruz, F. K. Chan, and S. C. $\mathrm{Ng}$, "Inflammatory bowel disease in Asia-a systematic review," Journal of Gastroenterology and Hepatology, vol. 27, no. 8, pp. 1266-1280, 2012.

[120] G. M. Holder, J. L. Plummer, and A. J. Ryan, "The metabolism and excretion of curcumin (1,7-bis-(4-hydroxy-3methoxyphenyl)-1,6-heptadiene-3,5-dione) in the rat," Xenobiotica, vol. 8, no. 12, pp. 761-768, 1978. 


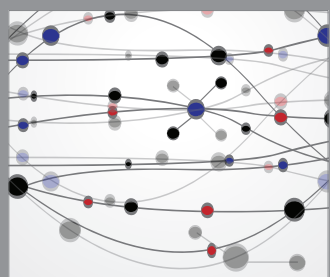

The Scientific World Journal
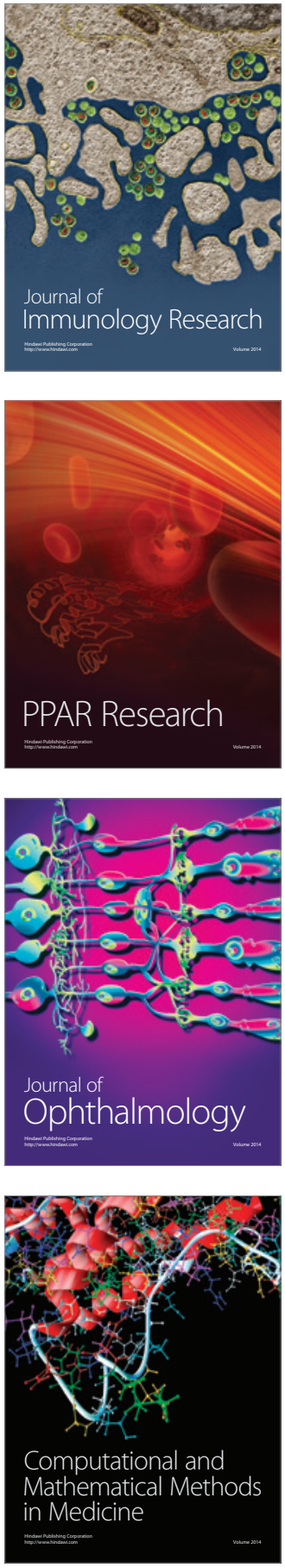

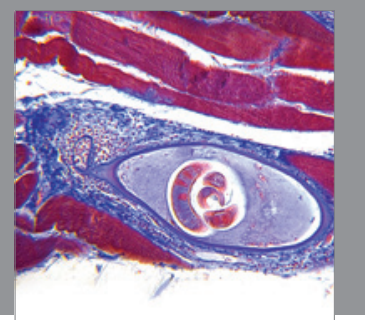

Gastroenterology

Research and Practice
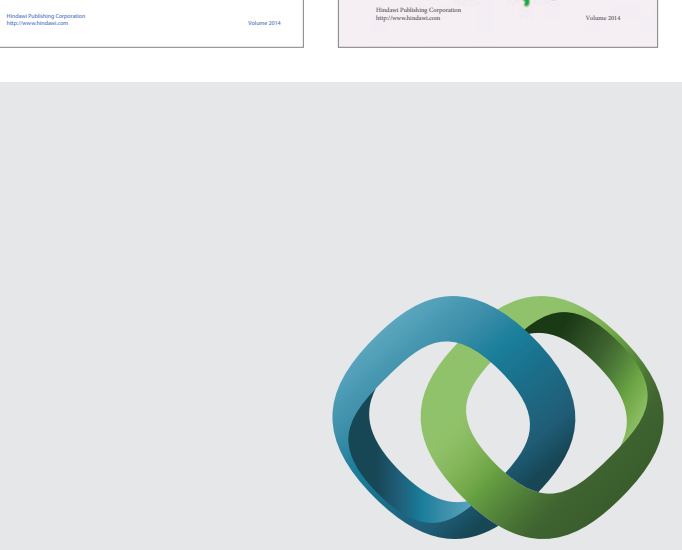

\section{Hindawi}

Submit your manuscripts at

http://www.hindawi.com
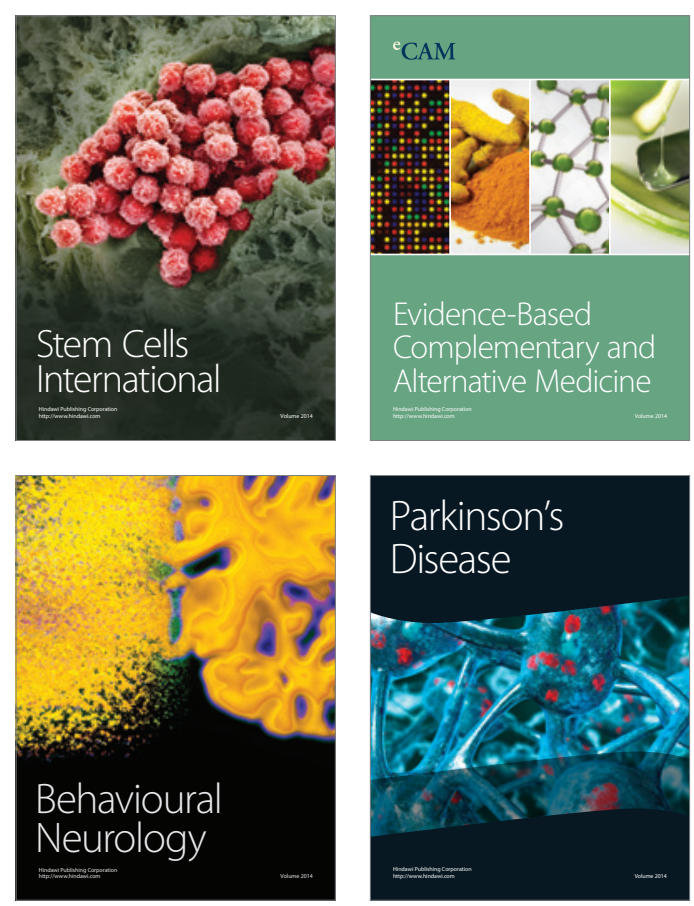

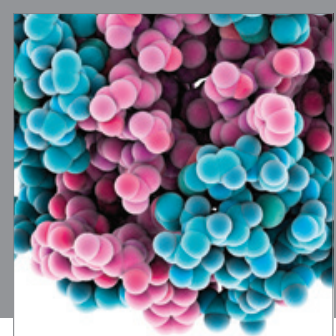

Journal of
Diabetes Research

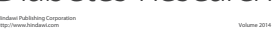

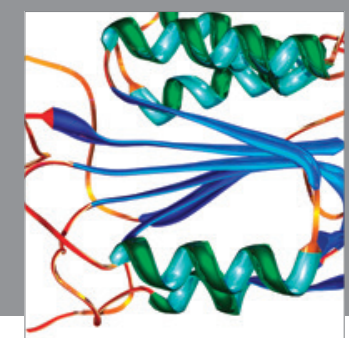

Disease Markers
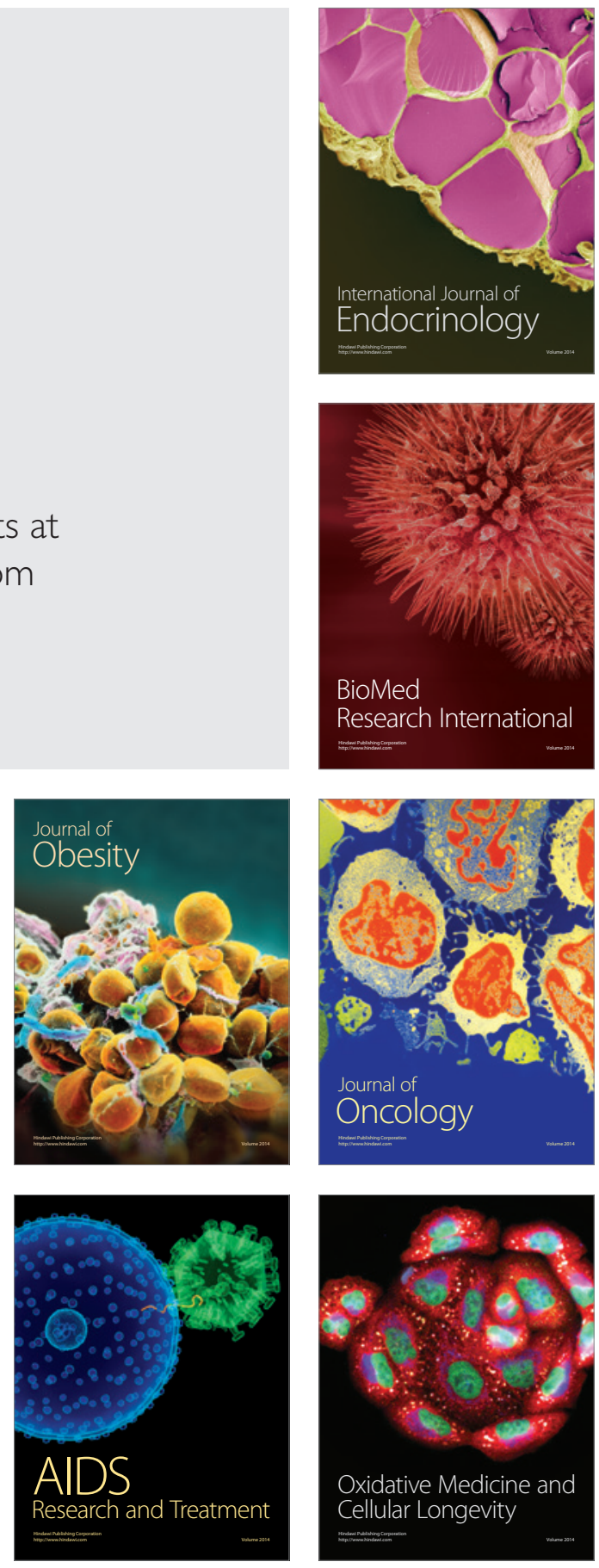